\title{
Selected Anti-nutritional Factors and In-vitro Protein Digestibility of Some Sorghum Types as Influenced by Germination Time During Malting
}

\author{
Mohammed Atanda Usman ${ }^{1}$, Mathew Kolawole Bolade ${ }^{2,}$, , Jelili Babatunde Hussein ${ }^{1}$ \\ ${ }^{1}$ Department of Food Science and Technology, Modibbo Adama University of Technology, Yola, Nigeria \\ ${ }^{2}$ Department of Food Science and Technology, Federal University of Technology, Akure, Nigeria \\ Email address: \\ mkbolade@futa.edu.ng (M. K. Bolade) \\ ${ }^{*}$ Corresponding author
}

To cite this article:

Mohammed Atanda Usman, Mathew Kolawole Bolade, Jelili Babatunde Hussein. Selected Anti-nutritional Factors and In-vitro Protein Digestibility of Some Sorghum Types as Influenced by Germination Time During Malting. International Journal of Food Science and Biotechnology. Vol. 3, No. 2, 2018, pp. 40-45. doi: 10.11648/j.ijfsb.20180302.11

Received: April 4, 2018; Accepted: April 23, 2018; Published: May 17, 2018

\begin{abstract}
The effect of germination time, during malting, on phytate and tannin concentration as well as on the in-vitro protein digestibility of some sorghum types was investigated. The increase in the germination time led to a decrease in the phytate content from the initial range of $1004.6-1097.4 \mathrm{mg} / 100 \mathrm{~g}$, at zero-hour germination, to a range of $457.2-626.3 \mathrm{mg} / 100 \mathrm{~g}$ at 48-hour germination time. A further decrease in the phytate content was obtained at 96-hour germination time with a range of $215.4-298.3 \mathrm{mg} / 100 \mathrm{~g}$. A maximum of 71.5-79.2\% phytate reduction capacity at 96-hour germination time was attainable with the sorghum types. The increase in germination time also caused the tannin concentration to decrease. The initial tannin concentration $(0.23-4.47 \mathrm{mg} / \mathrm{g})$, at zero-hour germination time, decreased to $0.15-3.35 \mathrm{mg} / \mathrm{g}$ at 48 -hour germination time while a range of $0.13-3.07 \mathrm{mg} / \mathrm{g}$ was obtained at 96-hour germination time. A maximum of $25.9-45.8 \%$ tannin reduction capacity at 96-hour germination time was attainable with the sorghum types. The in-vitro protein digestibility of the sorghum types increased from the initial level (32.1-45.1\%), at zero-hour germination time, to $42.8-61.3 \%$ at 48 -hour germination time while that of 96-hour germination time was 46.7-64.8\%. It may be concluded that the decrease in the anti-nutritional factors and improvement in the protein digestibility of sorghum types during the malting process was essentially a function of germination time and sorghum grain variability.
\end{abstract}

Keywords: Sorghum, Protein Digestibility, Germination, Malting, Anti-nutrient

\section{Introduction}

Sorghum (Sorghum bicolor (L) Moench) is an important cereal grain in the tropical arid and semi-arid zones of the world, and has been noted to be the fifth ranked cereal after wheat, maize, rice and barley in importance [1]. The consumption of sorghum serves as a major source of proteins and calories in the diets of people particularly in Africa [2], thereby meeting their food security requirements. The utilization of sorghum grains includes human food uses, serving as one of the most important weaning food cereals in low-income and high-income countries [3]. Other areas of sorghum usage, particularly in Africa, include the production of many traditional food products such as ogi, eko, kunnu and tuwo [4], fermented beverages such as mahewu [5], couscous and dolo [6], injera, kisra and ugali [7], among others. The nutritional quality of sorghum is dictated mainly by its chemical composition while the constraints that limit its utilization as food or feed is the occurrence of anti-nutrients such as phytate and tannin [8]. The phytate has been implicated to cause the essential minerals ( $\mathrm{Ca}, \mathrm{Mg}, \mathrm{Mn}, \mathrm{Zn}$, $\mathrm{Fe}$ and $\mathrm{Cu}$ ) not to be bioavailable and can also form a phytate-protein complex thereby interfering in protein utilization [9]. The negative consequence of tannin in sorghum-based diet has to do with its interference with protein digestion by binding dietary protein into an indigestible form [10].

Digestibility of sorghum protein is of immense interest particularly in Nigeria and to many African families who 
depend on sorghum as staple food. In such situations, sorghum is often the main source of dietary protein. Another nutritional constraint to the use of sorghum in human and animal diets is the poor digestibility of sorghum proteins on cooking [11]. Certain factors that have been implicated to contribute to poor protein digestibility of sorghum include grain organizational structure [12], possible interaction of sorghum proteins with non-protein components [13], and possible changes within the sorghum proteins themselves and these are disulphide crosslinking of protein molecules [14], racemization of amino acids and isopeptide formation [15]. The scientific efforts that have been made to improve sorghum protein digestibility essentially include the use of reducing agents in sorghum cooking [16], subjecting of sorghum grains to fermentation [17], the use of extrusion cooking in sorghum processing [18], and malting of sorghum grains [10].

In Africa and Asia, there have been series of genetic improvement on sorghum varieties and the areas of focus include that of disease resistance, high yielding capability, yield stability and nutrient enhancement, among others [19, 20]. The use of newly developed sorghum types is therefore very important so as to know the appropriateness of their food and feed usage. The present study was aimed at evaluating the role of germination time, during malting, on selected anti-nutritional factors and in-vitro protein digestibility of different sorghum types.

\section{Materials and Methods}

\subsection{Sources of Materials}

Three classes of sorghum grains were used for this study and these include (1) Local sorghum type (Pelipeli and Kwaya) obtained from Adamawa Agricultural Development Agency, Yola, Nigeria; (2) Improved sorghum type (SAMSORG-14 and SAMSORG-17) obtained from the Institute of Agricultural Research (IAR), Samaru, Nigeria; and (3) Hybrid sorghum type (Hybrid A and B) sourced from Lake Gerio Research Farm of the River Basin Development Authority (RBDA), Yola, Nigeria. All samples were respectively oven-dried to $8.9-10.2 \%$ moisture level at $50^{\circ} \mathrm{C}$ and then stored in different polyethylene bags at ambient temperature $\left(32 \pm 2^{\circ} \mathrm{C}\right)$ and $65 \%$ relative humidity until required.

\subsection{Malting of Sorghum Grains}

Experimental samples (300 g) of each sorghum grain type and barley were taken and the malting process follows the procedure of Palmer [21]. The grains were steeped in thrice quantity of water for $12 \mathrm{~h}$ with $1 \mathrm{~h}$ air rest after $6 \mathrm{~h}$ of steeping. For each air rest, the steeping water was changed. After steeping, the grains were sterilized by soaking in a solution of $1 \%$ sodium hypochlorite for $5 \mathrm{~min}$ before it was drained prior to germination. The steeped grains were spread on wet jute bags and covered with moist cotton cloth and left to sprout at room temperature $\left(32 \pm 2^{\circ} \mathrm{C}\right)$. The phytate, tannin and protein digestibility of the samples were determined immediately at $0 \mathrm{~h}$ at the onset of germination and later at 48 $\mathrm{h}$ and $96 \mathrm{~h}$ germination times respectively as described by Obizoba and Atii [22].

After germination, the grains were dried in Gallenkamp oven (BS model OV-160, England) at $50^{\circ} \mathrm{C}$ for $24 \mathrm{~h}$. Rootlets and shoots of the grains were separated from the kernels by rubbing the grain in a sieve (Endecotts Ltd, London, England) of $0.6 \mathrm{~mm}$ mesh size. The sieve allowed the rootlets and shoots to pass through but retained the kernels [23]. The unmalted and malted sorghum and barley samples were milled into flour with a hammer mill (Gibbons Electric, Essex, UK) to pass through 1-mm mesh size screen into fine flour. The samples were then stored at room temperature $\left(32 \pm 2^{\circ} \mathrm{C}\right)$ for subsequent analysis.

\subsection{Determination of Phytate Content}

Phytic acid content of samples was determined by the method described by Davies and Reid [24]. Samples (1 g each) was finely grounded and was extracted in $40 \mathrm{ml}$ of $0.5 \mathrm{M}$ nitric acid for $1 \mathrm{hr}$, filtered and $5.0 \mathrm{ml}$ of standard ferric chloride solution $(2 \mathrm{mg} / \mathrm{l})$ was added to each filtrate and incubated at $100^{\circ} \mathrm{C}$ for $20 \mathrm{~min}$. This was again filtered and 3 $\mathrm{ml} 0.004 \mathrm{M}$ ammonium thiocyanate added to the filtrate. The absorbance of the standard ferric chloride solution and the free $\mathrm{Fe} 3+$ remaining in solution was read on a spectrophotometer (SP6-400 UV spectrophotometer, PYE UNICAM) at $600 \mathrm{~nm}$. The results were converted to milligrams of phytate using the 4:6 atomic ratios for $\mathrm{Fe}: \mathrm{P}$ in ferric phytate [25] and the results expressed as $\mathrm{mg} / 100 \mathrm{~g}$ sample.

\subsection{Determination of Tannin Content}

Quantitative estimation of tannins was carried out using the modified vanillin $-\mathrm{HCl}$ procedure [26]. Sample (0.25 g) was extracted using $10 \mathrm{ml}$ of $4 \%(\mathrm{v} / \mathrm{v})$ concentrated $\mathrm{HCl}$ in methanol for $20 \mathrm{~min}$ in flask capped with parafilm. Individual test sample and sample blank was prepared by adding $5 \mathrm{ml}$ of $4 \% \mathrm{HCl}$ in methanol to $1 \mathrm{ml}$ aliquots of the sample extract. A set of catechin standard solution were prepared from the catechin stock solution. 5 millilitres of vanillin- $\mathrm{HCl}$ reagent (freshly prepared) was added to the extract $(1 \mathrm{ml})$ and to each $(1 \mathrm{ml})$ of the standard solution The colour was developed after $20 \mathrm{~min}$ at $300 \mathrm{C}$ and the absorbance of standard solution, sample extract and sample blank was read in a spectrophotometer at $500 \mathrm{~nm}$. A standard curve was prepared expressing catechin concentration, i.e amount of catechin $(\mu \mathrm{g} / \mathrm{mL})$ which gives a colour intensity equivalent to that given by tannins from the catechin standard solution readings after correcting for sample blank absorbance. The results were expressed as $\mathrm{mg} / \mathrm{g}$ sample.

\subsection{Determination of In-vitro Protein Digestibility}

In-vitro protein digestibility was determined by the method described by Mertz et al. [27]. Initial protein content of the sample was determined by micro-Kjeldahl nitrogen 
determination method. Sample of $200 \mathrm{mg}$ was mixed thoroughly with $20 \mathrm{ml}$ of buffered pepsin and later with 15 $\mathrm{ml}$ of buffered pepsin solution. A blank sample was similarly prepared the same way. The samples were then digested with pepsin and the sample residue collected after digestion were rolled up and inserted into Kjeldhal flask to determine the protein content of the sample using the micro-Kjeldahl nitrogen determination procedure. The percent protein before and after pepsin digestion was calculated using the formula given in the micro-Kjeldahl nitrogen determination method. The result of the percentage protein before and after pepsin digestion was inserted into the following equation:

$$
\text { Protein digestibility }(\%)=\frac{A-B}{\mathrm{~A}} \times 100
$$

where; $\mathrm{A}=$ protein in the sample

$\mathrm{B}=$ protein after pepsin digestion

\subsection{Statistical Analysis}

The SPSS statistical package (version 16.0) was used for the statistical analysis of results. All the results obtained for the statistical analysis were subjected to analysis of variance
(ANOVA) to determine differences within the samples [28] and Duncan Multiple Range Test was used to determine the differences within the variation at $95 \%$ confidence level $(\mathrm{p} \leq$ $0.05)$.

\section{Results and Discussion}

\subsection{Influence of Germination Time, During Malting, on the Phytate Content of Some Sorghum Types}

Table 1 shows the effect of germination time, during malting, on the phytate content of some sorghum types. The phytate content of unmalted sorghum types ranged between 1004.6 and $1097.4 \mathrm{mg} / 100 \mathrm{~g}$, with hybrid sorghum grain (Hybrid A) giving the lowest value while White Kaura (SSV2005503) gave the highest value. The barley grain (control) exhibited lowest phytate level $(620.7 \mathrm{mg} / 100 \mathrm{~g})$ than the sorghum types. Phytate is usually formed during plant seed maturation and so the differences in the phytate content may be a function of degree of maturation and other agricultural practices such as fertilizer application [29].

Table 1. Effect of Germination Time, during Malting, on the Phytate Content of Some Sorghum Types ${ }^{\text {. }}$

\begin{tabular}{|c|c|c|c|c|c|}
\hline \multirow{2}{*}{ Sorghum type } & \multirow{2}{*}{$\begin{array}{l}\text { Unmalted } \\
\text { (Zero-hour germination) } \\
\text { Phytate content } \\
\text { (mg/100g) }\end{array}$} & \multicolumn{2}{|c|}{ 48-hour germination } & \multicolumn{2}{|c|}{ 96-hour germination } \\
\hline & & $\begin{array}{l}\text { Phytate content } \\
(\mathrm{mg} / \mathbf{1 0 0 g})\end{array}$ & $\begin{array}{l}\text { Contributory reduction } \\
\text { capacity }^{2}(\%)\end{array}$ & $\begin{array}{l}\text { Phytate content } \\
(\mathrm{mg} / \mathrm{100g})\end{array}$ & $\begin{array}{l}\text { Contributory reduction } \\
\text { capacity }(\%)\end{array}$ \\
\hline \multicolumn{6}{|l|}{ Local sorghum grain } \\
\hline Pelipeli & $1044.7 \pm 1.4^{\mathrm{d}}$ & $617.1 \pm 2.3^{\mathrm{a}}$ & 41.0 & $298.3 \pm 3.2^{\mathrm{a}}$ & 71.5 \\
\hline Kwaya & $1094.5 \pm 5.3^{\mathrm{a}}$ & $626.3 \pm 5.5^{\mathrm{a}}$ & 42.8 & $266.1 \pm 3.2^{\mathrm{d}}$ & 75.7 \\
\hline Kilburi & $1084.9 \pm 1.6^{\mathrm{ab}}$ & $558.2 \pm 5.1^{\mathrm{d}}$ & 48.6 & $277.2 \pm 3.1^{\mathrm{bc}}$ & 74.5 \\
\hline \multicolumn{6}{|l|}{ Improved sorghum grain } \\
\hline Samsorg 17 (SK5912) & $1052.5 \pm 2.7^{\mathrm{d}}$ & $543.2 \pm 2.3^{\mathrm{e}}$ & 48.4 & $269.1 \pm 3.1^{\mathrm{b}}$ & 74.5 \\
\hline Samsorg-41 (ICSV400) & $1068.4 \pm 4.4^{\mathrm{c}}$ & $599.3 \pm 5.3^{b}$ & 44.0 & $271.2 \pm 2.6^{\mathrm{cd}}$ & 74.6 \\
\hline White Kaura (SSV2005503) & $1097.4 \pm 3.4^{\mathrm{c}}$ & $589.2 \pm 4.2^{\mathrm{b}}$ & 46.4 & $285.3 \pm 3.1^{\mathrm{b}}$ & 74.0 \\
\hline FF Katsina (SSV200503) & $1047.6 \pm 2.5^{\mathrm{d}}$ & $572.1 \pm 2.1^{\mathrm{c}}$ & 45.4 & $278.2 \pm 3.8^{\mathrm{bc}}$ & 73.5 \\
\hline \multicolumn{6}{|l|}{ Hybrid sorghum grain } \\
\hline HybridA & $1004.6 \pm 3.6^{\mathrm{f}}$ & $483.3 \pm 1.2^{\mathrm{g}}$ & 51.9 & $215.4 \pm 2.2^{f}$ & 78.6 \\
\hline Hybrid C & $1044.7 \pm 3.5^{\mathrm{de}}$ & $457.2 \pm 4.4^{\mathrm{h}}$ & 56.3 & $217.1 \pm 3.6^{\mathrm{ef}}$ & 79.2 \\
\hline Hybrid D & $1031.5 \pm 3.6^{\mathrm{e}}$ & $495.4 \pm 2.3^{\mathrm{f}}$ & 52.0 & $225.3 \pm 3.8^{\mathrm{e}}$ & 78.2 \\
\hline Barley (Control) & $620.7 \pm 2.1^{\mathrm{g}}$ & $359.1 \pm 6.6^{\mathrm{i}}$ & 42.2 & $211.1 \pm 4.2^{\mathrm{f}}$ & 66.0 \\
\hline
\end{tabular}

${ }^{1}$ Values are means \pm standard deviation of three determinations. Mean values within the same column having the same superscript are not significantly different at $\mathrm{p} \leq 0.05$.

${ }^{2}$ Contributory reduction capacity $(\%)$ was calculated with respect to the initial total phytate content at zero-hour germination.

The phytate content of sorghum types, at 48-hour germination time, was significantly lower $(\mathrm{p} \leq 0.05)$ than those of the unmalted counterparts. The phytate reduction capacity at 48 -hour germination time was between 41.0 and $56.3 \%$ with Pelipeli giving the lowest reduction capacity while hybrid sorghum grain (Hybrid C) gave the highest reduction capacity. The phytate reduction capacity in barley at 48 -hour germination time was observed to be $42.2 \%$. The general decrease in the phytate content of sorghum types at 48-hour germination time could be attributed to an increase in the phytase (enzyme) activity during the germination stage and this might have led to phytate degradation [30, 31].
There was further decrease in phytate content of the sorghum types at 96-hour germination time leading to an overall phytate reduction capacity of 71.5 to $79.2 \%$. The phytate reduction capacity in barley at 96-hour germination time was $66 \%$. The elongated germination time might have given rise to an increased phytate-phytase interaction thereby leading to a further degradation of phytate in the grains [31].

\subsection{Tannin Content of the Sorghum Types as Influenced by Germination Time}

Table 2 shows the effect of germination time, during malting, on the tannin content of some sorghum types. The 
tannin content of the unmalted sorghum grains ranged between 0.23 and $4.47 \mathrm{mg} / \mathrm{g}$ with the hybrid sorghum grain (Hybrid B) giving the lowest value while White Kaura (SSV2005503) gave the highest value. Tannin was not detected in hybrid sorghum grain (Hybrid D) and barley respectively. Tannins are essentially one of the phytochemicals present in plant seeds such as cereal grains and leguminous seeds [32]. They are usually deposited rapidly during the milk stage of development underneath the seed coat [33] and are principal polymerized products of flavan-3-ols and/or flavan-3,4-diols [34].

Table 2. Effect of Germination Time, during Malting, on the Tannin Content of Some Sorghum Types ${ }^{l}$.

\begin{tabular}{|c|c|c|c|c|c|}
\hline \multirow{2}{*}{ Sorghum type } & \multirow{2}{*}{$\begin{array}{l}\text { Unmalted (Zero-hour } \\
\text { germination) }\end{array}$} & \multicolumn{2}{|c|}{ 48-hour germination } & \multicolumn{2}{|c|}{ 96-hour germination } \\
\hline & & $\begin{array}{l}\text { Tannin content } \\
(\mathrm{mg} / \mathrm{g})\end{array}$ & $\begin{array}{l}\text { Contributory reduction } \\
\text { capacity }(\%)\end{array}$ & $\begin{array}{l}\text { Tannin content } \\
(\mathrm{mg} / \mathrm{g})\end{array}$ & $\begin{array}{l}\text { Contributory } \\
\text { reduction capacity }(\%)\end{array}$ \\
\hline \multicolumn{6}{|l|}{ Local sorghum grain } \\
\hline Pelipeli & $0.27 \pm 0.01^{\mathrm{bc}}$ & $0.23 \pm 0.05^{\mathrm{cd}}$ & 14.8 & $0.20 \pm 0.02^{\mathrm{cd}}$ & 25.9 \\
\hline Kwaya & $0.38 \pm 0.02^{\mathrm{bc}}$ & $0.32 \pm 0.03^{\mathrm{bc}}$ & 15.8 & $0.25 \pm 0.03^{\mathrm{bc}}$ & 34.2 \\
\hline Kilburi & $0.43 \pm 0.02^{\mathrm{bc}}$ & $0.35 \pm 0.02^{\mathrm{bc}}$ & 18.6 & $0.30 \pm 0.03^{\mathrm{b}}$ & 30.2 \\
\hline \multicolumn{6}{|l|}{ Improved sorghum grain } \\
\hline Samsorg 17 (SK5912) & $0.45 \pm 0.02^{\mathrm{bc}}$ & $0.33 \pm 0.05^{\mathrm{bc}}$ & 26.7 & $0.28 \pm 0.09^{b}$ & 37.8 \\
\hline Samsorg-41 (ICSV400) & $0.25 \pm 0.05^{\mathrm{bc}}$ & $0.20 \pm 0.05^{\mathrm{d}}$ & 20.0 & $0.18 \pm 0.06^{\mathrm{cd}}$ & 28.0 \\
\hline White Kaura (SSV2005503) & $4.47 \pm 0.21^{\mathrm{a}}$ & $3.35 \pm 0.19^{\mathrm{a}}$ & 25.1 & $3.07 \pm 0.24^{\mathrm{a}}$ & 31.3 \\
\hline FF Katsina (SSV200503) & $0.47 \pm 0.02^{\mathrm{b}}$ & $0.38 \pm 0.05^{\mathrm{b}}$ & 19.1 & $0.30 \pm 0.03^{\mathrm{b}}$ & 36.2 \\
\hline \multicolumn{6}{|l|}{ Hybrid sorghum grain } \\
\hline HybridA & $0.24 \pm 0.01^{\mathrm{bc}}$ & $0.15 \pm 0.06^{\mathrm{e}}$ & 37.5 & $0.13 \pm 0.03^{\mathrm{de}}$ & 45.8 \\
\hline Hybrid C & $0.24 \pm 0.01^{\mathrm{bc}}$ & $0.17 \pm 0.05^{\mathrm{e}}$ & 29.2 & $0.15 \pm 0.02^{\mathrm{de}}$ & 37.5 \\
\hline Hybrid D & $\mathrm{ND}^{3}$ & ND & - & ND & - \\
\hline Barley (Control) & ND & ND & - & ND & - \\
\hline
\end{tabular}

${ }^{1}$ Values are means \pm standard deviation of three determinations. Mean values within the same column having the same superscript are not significantly different at $\mathrm{p} \leq 0.05$.

${ }^{2}$ Contributory reduction capacity $(\%)$ was calculated with respect to the initial total tannin content at zero-hour germination.

${ }^{3} \mathrm{ND}=$ Not detected.

At 48-hour germination time, the tannin content was observed to decrease in all the sorghum types. Tannin was not detected in Hybrid D and barley respectively at 48-hour germination time. The decrease in the tannin content may be attributed to its partial break down during germination [35]. The tannin reduction capacity in the sorghum types at 48hour germination time ranged between 14.8 and $37.5 \%$ with Pelipeli (local sorghum grain) giving the lowest reduction capacity and Hybrid A giving the highest value. At 96-hour germination time, all the sorghum types experienced further break down of tannin giving a range of $0.13-3.07 \mathrm{mg} / \mathrm{g}$. The tannin reduction capacity was observed to range between 25.9 and $45.8 \%$, with Pelipeli (local sorghum grain) giving the lowest tannin reduction capacity while Hybrid A gave the highest reduction capacity.

\subsection{Effect of Germination Time on In-vitro Protein Digestibility of Sorghum Types}

The effect of germination time, during malting, on in-vitro protein digestibility of some sorghum types is presented in Table 3. The in-vitro protein digestibility of the unmalted sorghum grains ranged between 32.1 and $45.1 \%$, with Kilburi (local sorghum grain) exhibiting the lowest value while Hybrid B had the highest value. The protein digestibility of barley was observed to be $60.8 \%$. Protein digestibility is essentially a measure of the susceptibility of a protein to proteolysis [11]. A protein with high digestibility is regarded as being potentially better nutritionally than one of low digestibility due to its ability of providing more amino acids for absorption on proteolysis [11]. At 48-hour germination time, the in-vitro protein digestibility of each sorghum type was observed to increase significantly $(\mathrm{p} \leq 0.05)$ ranging between 42.8 and $61.3 \%$ with Kilburi and Hybrid A giving the lowest and highest values respectively. The improved protein digestibility of sorghum types at 48 -hour germination time may be attributed to increased enzymatic activities such as proteases which are capable of breaking down proteins during germination [36]. The incremental level in protein digestibility, at 48-hour germination time, ranged between 7.8 and $18 \%$ while the incremental level for barley was $6.7 \%$. The general increase in protein digestibility could also be attributed to the reduction in inhibitory activity of proteincomplexing reactions specifically through phytate and tannin respectively. The reduction in the level of phytate, which is capable of forming phytate-protein complex [9] as well as reduction in the concentration of tannin, which is capable of binding dietary protein into an indigestible form [10], all contributed to an improved protein digestibility. 
Table 3. Effect of Germination Time, during Malting, on the In-vitro Protein Digestibility of Some Sorghum Types ${ }^{l}$.

\begin{tabular}{|c|c|c|c|c|c|}
\hline \multirow[b]{2}{*}{ Sorghum type } & \multirow{2}{*}{$\begin{array}{l}\begin{array}{l}\text { Unmalted (Zero-hour } \\
\text { germination) }\end{array} \\
\begin{array}{l}\text { In-vitro protein } \\
\text { digestibility }(\%)\end{array}\end{array}$} & \multicolumn{2}{|c|}{ 48-hour germination } & \multicolumn{2}{|c|}{ 96-hour germination } \\
\hline & & $\begin{array}{l}\text { In-vitro protein } \\
\text { digestibility (\%) }\end{array}$ & $\begin{array}{l}\text { Incremental level in } \\
\text { protein digestibility }^{2}(\%)\end{array}$ & $\begin{array}{l}\text { In-vitro protein } \\
\text { digestibility (\%) }\end{array}$ & $\begin{array}{l}\text { Incremental level } \\
\text { in protein } \\
\text { digestibility }(\%)\end{array}$ \\
\hline \multicolumn{6}{|l|}{ Local sorghum grain } \\
\hline Pelipeli & $40.8 \pm 0.4^{\mathrm{e}}$ & $55.6 \pm 0.4^{\mathrm{d}}$ & 14.8 & $58.3 \pm 0.2^{\mathrm{g}}$ & 17.6 \\
\hline Kwaya & $35.6 \pm 0.2^{\mathrm{g}}$ & $51.2 \pm 0.4^{\mathrm{f}}$ & 15.6 & $52.1 \pm 0.1^{\mathrm{h}}$ & 16.5 \\
\hline Kilburi & $32.1 \pm 0.1^{\mathrm{h}}$ & $42.8 \pm 0.1^{\mathrm{h}}$ & 10.7 & $46.2 \pm 0.2^{\mathrm{i}}$ & 14.1 \\
\hline Telleri & $35.6 \pm 0.2^{\mathrm{g}}$ & $43.8 \pm 0.3^{\mathrm{h}}$ & 8.2 & $48.3 \pm 0.1^{\mathrm{h}}$ & 12.7 \\
\hline \multicolumn{6}{|l|}{ Improved sorghum grain } \\
\hline Samsorg 17(SK5912) & $43.2 \pm 0.1^{\mathrm{c}}$ & $56.5 \pm 0.1^{\mathrm{d}}$ & 13.3 & $59.8 \pm 0.1^{\mathrm{f}}$ & 16.7 \\
\hline Samsorg-41(ICSV400) & $37.3 \pm 0.1^{\mathrm{f}}$ & $46.3 \pm 0.3^{\mathrm{g}}$ & 9.0 & $48.5 \pm 0.1^{\mathrm{h}}$ & 11.2 \\
\hline White Kaura(SSV2005503) & $35.7 \pm 0.1^{\mathrm{g}}$ & $43.5 \pm 0.2^{\mathrm{h}}$ & 7.8 & $46.7 \pm 0.2^{\mathrm{i}}$ & 11.0 \\
\hline FF Katsina(SSV200503) & $42.2 \pm 0.1^{\mathrm{d}}$ & $56.2 \pm 0.1^{\mathrm{d}}$ & 14.0 & $58.1 \pm 0.1^{\mathrm{g}}$ & 15.9 \\
\hline \multicolumn{6}{|l|}{ Hybrid sorghum grain } \\
\hline HybridA & $43.1 \pm 0.1^{\mathrm{c}}$ & $61.7 \pm 0.1^{\mathrm{b}}$ & 18.0 & $63.1 \pm 0.1^{\mathrm{d}}$ & 20.0 \\
\hline Hybrid B & $45.1 \pm 0.2^{b}$ & $61.2 \pm 0.5^{b}$ & 16.0 & $64.8 \pm 0.2^{\mathrm{b}}$ & 19.7 \\
\hline Hybrid C & $40.7 \pm 0.1^{\mathrm{e}}$ & $54.4 \pm 0.1^{\mathrm{e}}$ & 13.7 & $60.5 \pm 0.3^{\mathrm{e}}$ & 19.8 \\
\hline Hybrid D & $42.6 \pm 0.1^{\mathrm{cd}}$ & $58.2 \pm 0.1^{\mathrm{c}}$ & 15.6 & $63.7 \pm 0.1^{\mathrm{c}}$ & 21.1 \\
\hline Barley(Control) & $60.8 \pm 0.1^{\mathrm{a}}$ & $67.5 \pm 0.3^{\mathrm{a}}$ & 6.7 & $79.5 \pm 0.1^{\mathrm{a}}$ & 18.7 \\
\hline
\end{tabular}

${ }^{1}$ Values are means \pm standard deviation of three determinations. Mean values within the same column having the same superscript are not significantly different at $\mathrm{p} \leq 0.05$.

${ }^{2}$ Incremental level in protein digestibility (\%) was calculated on the basis of initial digestibility at zero-hour germination.

At 96-hour germination time, there were further increases in the protein digestibility of all the sorghum types ranging between 46.7 and $64.8 \%$. The incremental level in protein digestibility, at 96-hour germination time, was between 11 and $21.1 \%$ with Kaura (SSV2005503) giving the lowest incremental level while Hybrid D gave the highest level. The elongated germination time might have increased the activities of the proteases thereby making the protein highly susceptible to digestibility. The degree of protein digestibility may be used as an indicator of protein availability in a food material [11].

\section{Conclusion}

The germination time during the malting process of sorghum types had revealed a positive influence on phytate and tannin content reduction as well as an improvement in protein digestibility of the sorghum types. At 96-hour germination time, the phytate reduction capacity could range between 71.5 and $79.2 \%$ while that of tannin could range between 25.9 and $45.8 \%$. In the case of in-vitro protein digestibility, the incremental level at 96-hour germination time could range between 11 and $21.1 \%$ for all the sorghum types evaluated under this study.

\section{References}

[1] FAOSTAT (2016). Annual production output for sorghum. [Internet document]. http://faostat3.fao.org/faostat-gateway/. Accessed on 11-11-2017.

[2] Belton, P. S. and Taylor, J. R. N. (2004). Sorghum and millets: Protein sources for Africa. Trends in Food Science and Technology, 15: 94-98.
[3] Abdel-Rahim, E. A. and El-Beltagi, H. S. (2010). Constituents of apple, parsley and lentil edible plants and their therapy treatments for blood picture as well as liver and kidneys functions against lipidemic disease. Electronic Journal of Environmental and Agricultural Food Chemistry, 9:11171127.

[4] Obilana, A. T. (1982). Traditional sorghum foods in Nigeria: Their preparation and Quality. In: Proceedings on the International Symposium on Sorghum Grain Quality, 28-31 October, 1981 (edited by L. W. Rooney, D. S. Murty and J. V. Mertin). Pp. 45-54. ICRISAT: Pantacheru, India.

[5] Bvochora, J. M., Reed, J. D., Read, J. S. and Zvauya, R. (1999). Effect of fermentation processes on proanthocyanidins in sorghum during preparation of Mahewu, a non-alcoholic beverage. Process Biochemistry, 35: 21-25.

[6] Dicko, M. H., Gruppen, H., Traoré, A. S., Voragen, A. G. J, and van Berkel, W. J. H. (2006). Sorghum grain as human food in Africa: relevance of content of starch and amylase activities. African Journal of Biotechnology, 5(5): 384-395

[7] Blandino, A., Al-Aseeria, M. E., Pandiellaa, S. S., Canterob, D. and Webb, C. (2003). Cereal-based fermented foods and beverages. Food Research International, 36: 527-543.

[8] Wu, G., Johnson, S. K., Bornman, J. F., Bennett, S. J., Singh, V., Simic, A., and Fang, Z. (2016). Effects of genotype and 439 growth temperature on the contents of tannin, phytate and in vitro iron availability of sorghum grains. PLoS One, 11(2).

[9] Gilani, G. S., Xiao, C. W. and Cockell, K. A. (2012). Impact of antinutritional factors in food proteins on the digestibility of protein and the bioavailability of amino acids and on protein quality. British Journal of Nutrition, 108: S315-S332.

[10] Onyango, C. A., Ochanda, S. O., Mwasaru, M. A., Ochieng, J. K., Mathooko, F. M. and Kinyuru, J. N. (2013). Effects of malting and fermentation on antinutrient reduction and protein digestibility of red sorghum, white sorghum and pearl millet. Journal of Food Research, 2(1): 41-49. 
[11] Duodu, K. G., Taylor, J. R. N., Belton, P. S. and Hamaker, B. R. (2003). Factors affecting sorghum protein digestibility. Journal of Cereal Science, 38: 117-131.

[12] Duodu, K. G., Nunes, A., Delgadillo, I., Parker, M. L., Mills, E. N. C., Belton, P. S., Taylor, J. R. N. (2002). Effect of grain organisational structure and cooking on sorghum and maize in vitro protein digestibility. Journal of Cereal Science, 35: 161174.

[13] Weaver, C. A., Hamaker, B. R. and Axtell, J. D. (1998). Discovery of sorghum germ plasm with high uncooked and cooked in vitro protein digestibilities. Cereal Chemistry, 75: 665-670.

[14] Mesa-Stonestreet, N. J., Alavi, S. and Bean, S. R. (2010) Sorghum proteins: the concentration, isolation, modification, and food applications of kafirins. Journal of Food Science, 75: 90-104.

[15] Schaafsma, G. (2012). Advantages and limitations of the protein digestibility-corrected amino acid score (PDCAAS) as a method for evaluating protein quality in human diets. British Journal of Nutrition, 108: S333-S336.

[16] Goodarzi-Boroojeni, F., Mader, A., Knorr, F., Ruhnke, I., Röhe, I., Hafeez, A., Männer, K. and Zentek, J. (2014). The effects of different thermal treatments and organic acid levels on nutrient digestibility in broilers. Poultry Science, 93(5): $1159-1171$

[17] Alka, S., Neelam, Y. and S. Shruti, S. (2012). Effect of fermentation on physicochemical properties and in vitro starch and protein digestibility of selected cereals. International Journal of Agriculture and Food Science, 2(3): 66-70.

[18] Brennan, M. A., Derbyshire, E., Tiwari, B. K. and Brennan, C. S. (2013). Ready-to-eat snack products: the role of extrusion technology in developing consumer acceptable and nutritious snacks. International Journal of Food Science and Technology, 48: 893-902.

[19] Blümmel, M., Vishala, A., Ravi, D., Prasad, K. V. S. V., Reddy, C. R. and Seetharama, N. (2010). Multienvironmental investigations of food-feed trait relationships in Kharif and Rabi sorghum (Sorghum bicolor (L) Moench) over several years of cultivars testing in India. Animal Nutrition and Feed Technology, 10S: 11-21.

[20] Brocke, K. V., Trouchea, G., Weltzienb, E., BarroKondomboc, C. P., Gozé, E., and Chantereau, J. (2010). Participatory variety development for sorghum in Burkina Faso: Farmers' selection and farmers' criteria. Field Crops Research, 119: 183-194.

[21] Palmer, G. H. (1989). Cereals in malting and brewing. In: Cereal Science and Technology (G. H. Palmer, ed.), Aberdeen University press: Aberdeen, Scotland. 61: 462-471.

[22] Obizoba, I. C. and Atii, J. V. (1994). Evaluation of the effect of processing techniques on the nutrient and antinutrient content of pearl millet (Pennisetum glaucum) seeds. Plant Foods for Human Nutrition, 45: 23-28.

[23] Morall, P., Boyd, H. K., Taylor, R. N. J. and van Der Walt, W.
H. (1986). Effect of germination time, temperature and moisture on malting of sorghum. Journal of the Institute of Brewing, 92: 439-445.

[24] Davies, N. T. and Reid, H. (1979). An evaluation of the phytate, zinc, copper, iron and manganese content of, and zinc availability from soya- based textured -vegetable-protein meat -substitute or meat-extruders. British Journal of Food Science, 49: 1486-1488.

[25] Garcial- Estepa, R. M., Guerra- H., E. and Garcia- V. B. (1999). Phytic acid content in milled cereal products and breads. Food Research International, 32: 217-221.

[26] Gomez M. T., Obilana, A. B., Martin, D. F., Madzuanuse, M. and Manyo E. S. (1997). Manual of laboratory procedures for quality evaluation of sorghum and mill. International Crops Research Institute for the Semi Arid and Tropics (ICRSAT). India pp. 64.

[27] Mertz, E. T., Hassen, M. M., Cairns-Whittern, C., Kirleis, A. W., Tu, L. and Axtell, J. D. (1984). Pepsin digestibility of proteins in sorghum and other major cereals. Proceedings of the National Academy of Science, USA, 81: 1-2.

[28] Snedecor, G. W and Cochran, W. G. (1987). Statistical methods. 17th ed. The Iowa State University Press, Ames, IA. USA, pp. 221-222.

[29] Wu, P., Tian, J-C., Walker, C. E., Wang, F-C. (2009). Determination of phytic acid in cereals - a brief review. International Journal of Food Science and Technology, 44: $1671-1676$.

[30] Maghoub, S. E. O. and Elhag, S. A. (1998). Effect of milling, soaking, malting, heat-treatment and fermentation on phyate level of four Sudanese sorghum cultivars. Food Chemistry, 61: 77-80.

[31] Helmalatha, S., Platel, K. and Srinivasan, K. (2007). Influence of germination and fermentation on bioaccessability of zinc and iron from food grains. European Journal of Clinical Nutrition, 61:342-348.

[32] Nyachoti, C. M., Atkinson, J. L. and Leeson, S. (1997). Sorghum tannins: a review. World's Poultry Science Journal, 53: 5-21.

[33] Reichert, R. D., Mwasaru, M. A. and Mukuru, S. Z. (1988). Characterization of coloured-grain sorghum lines and identification of high-tannin lines with good dehulling characteristics. Cereal Chemistry, 65: 165-170.

[34] Awika, J. M. and Rooney, L. W. (2004). Sorghum phytochemicals and their potential impact on human health-a review. Phytochemistry, 65: 1199-1221.

[35] Dicko, M. H., Gruppen, H., Traore, A. S., van Berkel, W. J. H. and Voragen, A. G. J. (2005). Evaluation of the effect of germination on phenolic compounds and antioxidant activities in sorghum varieties. Journal of the Agricultural and Food Chemistry, 53: 2581-2588.

[36] Elkhalifa, A. E. O. and Bernhardt, R. (2010). Influence of grain germination on functional properties of sorghum flour. Food Chemistry, 12: 387-392. 